\title{
AKSEPTABILITAS TERJEMAHAN DONGENG HAENSEL UND GRETEL
}

\section{Rosyidah, Deddy Kurniawan dan Desti Nur Aini}

\author{
Jurusan Sastra Jerman Fakultas Sastra Universitas Negeri Malang
}

\begin{abstract}
This study was conducted to explore and describe the clarity, the naturalness, the emotional expressions and the styles used in the translation of Hansel and Gretel fairytale. The data were collected through document analysis and analysed by using three main steps, namely data reduction, data display, and data conclusion and verification. The results showed that (1) there are many forms which are not clear and not easy to understand; (2) there are many forms which are correct grammatically but not natural; (3) emotion is expressed through words, phrases and sentences which describe anger, fear, sadness, joy and calmness; and (4) there are five styles used by the translator: simile, hyperbol, assonace, repetition and personification.
\end{abstract}

Keywords: translation of fairy tale, clearness, naturalness, emotional expression, styles

\begin{abstract}
Abstrak: Tujuan penelitian ini adalah untuk mengeksplorasi dan mendeskripsikan kejelasan, kealamiahan/kewajaran terjemahan dongeng Haensel und Gretel, pengekspresian emosi, dan untuk mendeskripsikan gaya bahasa yang terdapat di dalamnya. Data dikumpulkan dengan analisis dokumen dan dianalisis melalui tiga tahap utama, yaitu reduksi data, penyajian data, dan penarikan kesimpulan dan verifikasi. Hasil penelitian menunjukkan bahwa dalam terjemahan dongeng Haensel und Gretel terdapat (a) bentuk-bentuk bahasa: kata, frase, dan kalimat yang tidak mudah dipahami dan ambigu sehingga pesan yang ingin disampaikan tidak jelas/tidak begitu jelas; (b) bentuk-bentuk yang tidak wajar, bentuk-bentuk yang mungkin benar dari segi tatabahasa, tetapi tidak lazim digunakan; (c) pengekspresian emosi ditunjukkan melalui kata, frase, dan kalimat yang menggambarkan kemarahan, ketakutan, kesedihan, kesenangan, dan ketenangan tokoh-tokoh ceritanya; (d) terdapat lima gaya bahasa, yaitu simile, hiperbola, asonansi, repetisi, dan personifikasi.
\end{abstract}

Kata Kunci: terjemahan dongeng, kejelasan, kewajaran, ekspresi emosi, gaya bahasa

Dongeng tergolong teks naratif yang sangat khas. Dalam dongeng, masalah manusia digambarkan secara simbolis dan kebenaran tentang manusia yang tidak terbatas waktu dan budaya diungkapkan. Helmling dan Wackwitz (1986) menyebutkan bahwa dongeng merupakan cerita pendek dengan kalimat pembuka dan penutup yang relatif tetap atau sama. Terkait dengan fungsinya, Nurgiyantoro (2005) menjelaskan bahwa dongeng tergolong karya 
sastra anak yang berfungsi untuk menghibur dan untuk mewariskan nilai-nilai moral yang terkandung di dalamnya dan diyakini kebenarannya oleh masyarakat.

Sebagaimana karya-karya sastra asing lainnya, dongeng terjemahan tidak luput dari kritik. Kritik terhadap dongeng terjemahan di Indonesia menyoal banyaknya dongeng berbahasa asing yang diterjemahkan dengan kurang baik sehingga gagasan dan informasi yang disampaikan oleh penulis asalnya tidak mampu ditangkap dengan baik oleh pembaca Indonesia. Dengan kata lain, hasil terjemahannya sulit dipahami oleh pembaca Indonesia. Kesulitan yang dijumpai bisa jadi tidak sekedar dari segi bahasa semata, seperti jalinan kata yang rumit atau kalimat yang menjadi tak berarti dalam bahasa Indonesia, tetapi diperparah dengan pengadopsian kultur asing secara mentah-mentah, tanpa penyesuaian dengan budaya Indonesia, ketidaksesuaian interpretasi, dan penyelewengan konteks. Singkat kata, terjemahanpun menjadi tidak berterima dan tidak berkualitas.

Menurut Haque (2012), kesulitan dalam penerjemahan terletak pada fakta bahwa isi dan gaya bsu harus direproduksi dalam bsa. Ketika melakukan proses penerjemahan dongeng, penerjemah tentunya dituntut untuk memberi perhatian lebih pada pembaca anakanak dan harus menyadari bahwa produknya, dongeng terjemahan adalah teks sastra anak "yang sudah berbeda" dari teks sastra anak/dongeng dalam bahasa aslinya. Damono (2013) mengatakan, bahwa sastra yang diterjemahkan otomatis menjadi bagian dari bahasa sasaran. Pernyataan senada disampaikan oleh Ahmad (2013), yaitu bahwa teks sastra terjemahan bukan lagi bagian dari khazanah sastra asalnya, tetapi menjadi bagian dari khazanah sastra dalam bahasa sasaran.

Budaya berpengaruh dalam proses penerjemahan dan akan memberi warna pada produknya. Jika hal ini tidak dipahami dengan baik oleh seorang penerjemah, hasil terjemahannya akan sulit dipahami oleh khalayak pembaca Indonesia dan pesan yang ditulis oleh pengarang aslinya tentu tidak akan sampai kepada pembaca terjemahan tersebut. Oleh sebab itu, Hervey, dkk. (2006), Kadric, dkk. (2010), dan Glodjovic (2010) mengingatkan bahwa perbedaan budaya dalam proses penerjemahan itu sangat penting dan harus diperhatikan. Implikasinya adalah ketika sebuah karya sastra asing diterjemahkan ke dalam bahasa Indonesia, perlu dilakukan penyesuaian bahasa, baik secara kultural, sosial, dan kontekstual. Singkat kata, terjemahan sebagai produk bisa baik, apabila proses penerjemahannya baik (analog dari Machali,2009).

Salam (2001) berpendapat bahwa persoalan akseptabilitas bahasa selalu menjadi salah satu faktor penentu akan keberadaan dan identitas teks sastra. Mansor (2012) mengatakan bahwa "Acceptability is a target-reader approach where a translation follows the norms of the target language and culture". Artinya, akseptabilitas adalah sebuah pendekatan penerjemahan yang berorientasi pada pembaca bahasa sasaran dengan mengikuti normanorma bahasa dan budaya bahasa. Aspek-aspek akseptabilitas bahasa yang dibahas dalam penelitian ini adalah kejelasan, kewajaran, pengekspresian emosi, dan gaya bahasa yang banyak ditemukan dalam terjemahan dongeng Haensel dan Gretel versi Debby Natalia.

\section{METODE}

Penelitian ini didesain sebagai penelitian deskriptif dengan pendekatan kualitatif yang tergolong studi kasus. Penelitian ini dikategorikan studi kasus karena bertujuan mendeskripsikan akseptabilitas dongeng terjemahan Haensel und Gretel versi tertentu. Menurut Yin (1994), sebuah penelitian dapat disebut studi kasus, apabila penelitian tersebut berupaya melakukan eksplorasi terhadap suatu latar (a detailed examination of one setting), 
atau satu peristiwa tertentu (one particular event), atau satu subjek (one single subject) atau satu tempat penyimpanan dokumen (one single depository of document) dengan cara menginvestigasi secara eksploratif, deskriptif, dan utuh (wholeness) fenomena sementara dalam konteks kehidupan nyata (real live context). Dalam penelitian ini, studi kasus dirancang untuk mengeksplorasi faktor kejelasan, kewajaran, pengekspresian emosi, dan gaya bahasa dalam terjemahan dongeng Haensel dan Gretel versi Debbi Natalia yang diterbitkan oleh penerbit PT Gramedia Pustaka Utama pada tahun 2013. Studi kasus ini menggunakan sumber data berupa dokumen/analisis dokumen. Rancangan umum ini dilaksanakan berdasarkan kerangka yang dikemukakan oleh Yin (1994), yang meliputi empat tahap: (1) perencanaan/desain studi kasus yang terdiri dari penentuan keahlian yang dibutuhkan serta pengembangan dan pemeriksaan ulang protokol, (2) pelaksanaan studi kasus yang meliputi perencanaan pengumpulan data dan pelaksanaan penggunaan instrumen, (3) analisis data studi kasus atau penentuan strategi analisis, dan (4) menarik kesimpulan, mengembangkan rekomendasi, dan menyatakan implikasi.

Data penelitian ini berupa kata, frase, dan kalimat yang terdapat dalam dongeng terjemahan Haensel und Gretel yang dianggap melanggar norma-norma/kaidah tatabahasa bahasa Indonesia. Sesuai dengan pertanyaan penelitian, maka data dikelompokkan menjadi empat, yaitu: (1) data kejelasan makna, (2) data kealamiahan/kewajaran terjemahan, (3) pengekspresian emosi, dan (4) data gaya bahasa.

Sesuai dengan definisi akseptabilitas dalam konteks terjemahan yang telah dijadikan acuan dalam penelitian ini,dapat dikatakan bahwa indikator akseptabilitas sebuah terjemahan yang paling sederhana, tetapi mendasar adalah apabila kenyamanan membaca pembaca terjemahan tersebut terganggu. Ketidaknyamanan tersebut akan membuat pembaca berhenti membaca. Oleh karena itu, penelitian akseptabilitas sebuah terjemahan sudah bisa dilakukan hanya dengan membaca teks terjemahan (bsa) itu sendiri, meskipun idealnya teks aslinya (bsu) dijadikan sumber pembanding. Oleh sebab itu, dalam penelitian ini, hanya digunakan satu sumber data, yaitu dongeng bsa Haensel dan Gretel, terjemahan dari Hansel and Gretel dalam The Oxford Treasury of Fairy Tales yang diceritakan oleh Geraldine McCaughrean (2003). Dongeng bsa tersebut terdapat dalam buku kumpulan dongeng yang berjudul 20 Dongeng Terbaik Sepanjang Masa yang diterbitkan oleh PT Gramedia Pustaka Utama pada tahun 2013, dialihbahasakan oleh Debbi Natalia, dan dieditori oleh Nina Andiana.

Penjaringan data penelitian dilakukan dengan dua teknik. Secara rinci kedua teknik tersebut diuraikan sebagai berikut. Pertama, data dikumpulkan lewat pemeriksaan atau lebih tepatnya pengidentifikasian kata, frase, dan kalimat dalam terjemahan dongeng Haensel und Gretel yang tidak berterima dalam bahasa Indonesia. Selanjutnya, dilakukan pencatatan semua data makna dan data gaya yang teridentifikasi serta komentar-komentar peneliti terkait kejelasan, kewajaran, pengekspresian emosi, dan gaya dalam dongeng versi terjemahan. Untuk keperluan pengumpulan data, keseluruhan teks bsa dibaca dan diperiksa berulangulang. Selanjutnya, dilakukan penandaan kata, frase, dan kalimat yang merujuk pada kejelasan, kewajaran, pengekspresian emosi, dan gaya bahasa.

Berpijak pada tujuan penelitian ini, data yang terkumpul dianalisis baik ketika pengumpulan data masih berlangsung maupun ketika pengumpulan data sudah selesai, dengan harapan peneliti dapat memahami data secara maksimal sehingga memungkinkannya untuk menyajikan hasil penelitiannya kepada orang lain dengan jelas. Adapun model analisis data yang digunakan adalah model interaktif yang dirancang oleh Miles dan Huberman (1984). Rangkaian kegiatan analisis data tersebut dilakukan melalui lima tahap utama, yaitu (1) reduksi data, (2) penyajian data, dan (3) penarikan kesimpulan. 
Pada tahap reduksi data, dilakukan pemilahan data-data yang relevan dengan tujuan penelitian. Selain itu, informasi-informasi penting disusun secara sistematis serta ditonjolkan pokok-pokok penting agar lebih mudah dikendalikan.

Pada tahap selanjutnya, dilakukan penyajian data untuk melihat gambaran keseluruhan atau bagian-bagian tertentu. Pada tahap penyajian data ini pula diklasifikasikan dan disajikan data sesuai pokok permasalahan, diawali dengan pengodean setiap subpokok masalah. Untuk melihat hubungan antardata dilakukan penyusunan matriks.

Pada tahap penarikan kesimpulan,yakni untuk mencari makna data dicari hubungan, persamaan/perbedaan antar data dengan membandingkan kesesuaian data dengan makna yang terkandung dengan konsep-konsep dasar penelitian.

Selain tahapan-tahapan di atas, dalam studi kasus ini digunakan triangulasi peneliti untuk menjamin keabsahan data dengan harapan validitas internal data akan terjamin keabsahannya (Moleong, 2007). Setelah itu dilakukan pengecekan ulang keseluruhan proses untuk mendapatkan hasil analisis dan kesimpulan yang meyakinkan.

\section{HASIL}

\section{Kejelasan}

Dalam terjemahan, kejelasan dapat dimaknai sebagai keberhasilan penerjemah mengomunikasikan maksud penulis teks bsu kepada pembaca teks bsa. Hasil penelaahan aspek kejelasan dalam dongeng terjemahan Haensel und Gretel menunjukkan bahwa banyak sekali kata, frase, dan kalimat yang digunakan atau diformulasikan dengan kurang/tidak jelas dan kurang logis sehingga pesan yang ingin disampaikannya kurang/tidak jelas pula. Ketidakjelasan tampak dalam contoh-contoh yang disajikan berikut ini.

(1) Ayah mereka sangat menyayangi Haensel dan Gretel.

(2) Ketika Hansel mendengar tentang rencana itu, ia menenangkan tangisan adiknya .

(3) Si penyihir terbakar dengan kobaran ungu.

Pada contoh-contoh di atas, kata, frase, atau klausa yang dicetak tebal merupakan bentukbentuk ketidakjelasan yang secara umum tampak biasa-biasa saja. Pada contoh yang pertama, frase ayah mereka yang digunakan penerjemah untuk mengawali dongeng terjemahannya, jelas sekali ketidakjelasannya karena kata mereka seharusnya digunakan untuk merujuk orang-orang yang sebelumnya sudah diketahui atau disebut. Pada contoh kedua, klausa ia menenangkan tangisan adiknya seyogyanya digunakan setelah penerjemah memberi informasi terlebih dahulu bahwa adiknya menangis, baik secara eksplisit maupun implisit. Demikian juga dengan contoh yang ketiga. Frase dengan kobaran ungu sangat tidak jelas, apakah yang dimaksud kobaran ungu itu api yang membakar si penyihir atau api menjadi berwarna ungu karena membakar si penyihir.

Selain itu, ada juga bentuk-bentuk lain yang tidak terlalu jelas, yang terkait dengan penerjemahan budaya spesifik. Perhatikan bentuk-bentuk berikut ini.

(1) ... setiap cerobong asap mengeluarkan gula barley.

(2) ..., melangkah di atas hamparan bunga parma violet.

(3) Di sana angsa-angsa sebesar gondola Venezia.

Ketiga contoh data tersebut menyiratkan bahwa penerjemah tidak terlalu memahami makna gula barley, bunga parma, dan gondola Venezia. Ada prosedur penerjemahan yang 
dapat diterapkan oleh penerjemah untuk mengatasi masalah penerjemahan aspek budaya spesifik atau padanan leksikal untuk konsep yang tidak dikenal, misalnya, dengan membuat frase deskriptif, sebagaimana yang disarankan oleh Larson (1984). Terjemahan yang disarankan: ... gula barley $\rightarrow$... sejenis gula yang disebut gula barley; ... bunga parma $\rightarrow$... sejenis bunga berwarna ungu yang biasa disebut bunga parma; dan gondola Venezia $\rightarrow$... sejenis perahu tradisional di Itali (Venezia) yang dikenal dengan sebutan gondola.

\section{Kewajaran}

Hasil telaah teks dongeng terjemahan Haensel und Gretel menunjukkan bahwa banyak sekali bentuk-bentuk yang tidak wajar di dalamnya. Perhatikan tiga contoh berikut ini.

(1) "Tunggu aku di sini," katanya, ... "Aku akan menjemput kalian ... Semoga Tuhan mengampuniku jika aku tidak menjemput kalian.

(2) Ia menjatuhkan jejak remah roti, ...

(3) Tiba-tiba, dengan tawa melengking yang memecahkan bejana air, ... .

Ketiga contoh di atas menunjukkan ketidakwajaran bentuk. Pada contoh yang pertama, tampak bahwa kata $\boldsymbol{a k} \boldsymbol{u}$ digunakan dalam kalimat langsung yang dituturkan oleh ayah Haensel dan Gretel dalam sebuah percakapan dengan kedua anak tersebut. Dalam konteks Indonesia, kata $a k u$ tidak wajar digunakan oleh orang tua kepada anaknya. Pada contoh yang kedua, ketidakwajaran bentuk terletak pada penggunaan kata jejak dalam konteks kalimat tersebut. Ada kesan penerjemah memaksakan kata tersebut untuk memendekkan kalimat dari: Ia menjatuhkan remah roti untuk melacak jejaknya (agar meninggalkan jejak). Adapun pada contoh yang ketiga, tampak bahwa frase tawa melengking yang memecahkan bejana air tidak lazim/wajar digunakan dalam budaya Indonesia dan terasa sangat asing.

\section{Pengekspresian Emosi}

Berdasarkan hasil analisis data, diketahui bahwa dalam terjemahan dongeng Haensel und Gretel, pengekspresian emosi dilakukan oleh penerjemah melalui kata, frase, dan kalimat yang menggambarkan kemarahan, ketakutan, kesedihan, kesenangan, dan ketenangan tokohtokoh ceritanya. Pengekspresian kelima aspek emosi tersebut disajikan dalam contoh-contoh berikut ini.

\section{Kemarahan}

(1) ... mereka dapat mendengar bentakan dan geraman sang ibu tiri saat mencerca suaminya.

(2) “Dasar bodoh! Bisa-bisanya kau membiarkan mereka menemukan jalan pulang! Kerjamu besok harus lebih baik, atau kita akan kelaparan!"

(3) "Pokoknya merangkaklah ke dalam dan nyalakan kayu bakarnya,dasar anak bodoh!" kata si penyihir.

Pada contoh pertama, kemarahan terekspresikan dalam bentuk kalimat tidak langsung/pernyataan, tepatnya pada kata bentakan dan geraman. Adapun pada contoh kedua dan ketiga ekspresi kemarahan ditampakkan oleh keseluruhan kalimat yang berbentuk kalimat langsung. 


\section{Ketakutan}

(1) Gretel mulai menangis.

(2) Gretel mencengkeram tangan kakaknya, ketakutan.

(3) ..., dan Gretel mulai menangis.

Contoh-contoh tersebut menunjukkan emosi ketakutan tokoh Gretel. Pada contoh pertama dan ketiga, melalui konteks kalimat, baru dapat diketahui bahwa kata menangis merupakan ekspresi ketakutan. Tidak demikian halnya dengan contoh yang kedua yang menggunakan kata performatif ketakutan untuk mengekspresikan rasa takut.

\section{Kesedihan}

(1) “Tunggu aku di sini,” katanya, mencium mereka lalu menghapus air matanya sendiri.

(2) Haensel dan Gretel mencari, berlari, dan memanggil, tetapi mereka hanya sendirian di tengah hutan besar itu, benar-benar tersesat tanpa daya.

(3)... Akan kucarikan sesuatu untuk dimakan -sesuatu, entah bagaimana caranya..."

Emosi kesedihan ditunjukkan dengan berbagai ekspresi. Pada contoh-contoh yang disajikan, ekspresi sedih tampak jelas pada frase air mata dan melalui konteks. Pada contoh kedua dan ketiga emosi kesedihan baru bisa diketahui melalui konteks.

\section{Kegembiraan/rasa senang}

(1) Raut wajah ayah mereka ketika membukakan pintu begitu gembira.

(2) “Anak-anak, ya? Wah menyenangkan sekali.

(3) ..., ia memeluk kedua anaknya yang hilang itu erat-erat sampai mereka tak bisa bicara.

Kegembiraan dapat diekspresikan dengan banyak cara. Pada contoh pertama, kata gembira merupakan petunjuk yang sangat jelas. Pada contoh kedua, ada kata menyenangkan, sedangkan pada contoh ketiga, perasaan gembira atau senang diungkapkan melalui keseluruhan klausa.

\section{Ketenangan}

(1) "Jangan takut," kata Haensel.

(2) Haensel menenangkan tangis adiknya.

(3) Haensel tidak khawatir. Ia bahkan bersiul-siul sambil menunggu.

Sikap tenang/ketenangan merujuk pada sikap tidak takut atau gentar menghadapi berbagai situasi. Pada contoh yang pertama, kalimat imperatif "jangan takut" mengandung makna "tenanglah" dikatakan oleh Haensel yang tenang-tenang saja menghadapi situasi. Adapun pada contoh kedua, kata menenangkan mengandung makna si pelaku, dalam hal ini Haensel bersikap tenang, sementara pada contoh ketiga sikap tenang tampak pada keseluruhan kalimat.

\section{Gaya Bahasa}

Dalam dongeng terjemahan Haensel und Gretel terdapat beberapa gaya bahasa. Berikut ditampilkan contohnya. 
(1) ..., wajahnya keriput seperti bola kertas remasan.

(2) ... menguasai rumah itu dengan lidahnya yang tajam, ...

(3) ... dan Gretel mencari, berlari, dan memanggil, ...

(4) ..., "Terlalu kurus! Terlalu kurus!..."

(5) Kelaparan membentangkan sayapnya dan terbang menjauh ...

Pada contoh pertama, tampak jelas bahwa gaya bahasa yang digunakan adalah simile. Pada contoh kedua, digunakan majas hiperbola, sedangkan pada contoh ketiga gaya bahasa asonansi atau persamaan bunyi, dan pada contoh keempat repetisi. Adapun contoh terakhir merupakan gaya bahasa personifikasi. Penggunaan kelima gaya bahasa tersebut dalam terjemahan dongeng Haensel und Gretel menunjukkan upaya penerjemahan efek bsu oleh penerjemah.

\section{PEMBAHASAN}

\section{Kejelasan}

Hasil analisis data aspek kejelasan dalam dongeng terjemahan Haensel und Gretel menunjukkan bahwa banyak sekali kata, frase, dan kalimat yang sulit dipahami sehingga tidak jelas pesan apa yang ingin disampaikannya. Untuk dapat memahami kata, frase, dan kalimat yang tidak jelas tersebut, teks perlu dibaca secara berulang. Sehubungan dengan hal tersebut, Larson (1984) mengatakan bahwa sebuah terjemahan mungkin sudah tepat, tetapi mungkin masih ambigu dan tidak atau kurang dapat dimengerti oleh khalayak pembacanya. Oleh sebab itu, bentuk-bentuk bahasa yang digunakan dalam teks terjemahan harus dapat membuat amanat teks sumber mudah dimengerti oleh pembaca teks terjemahan, seperti teks sumber itu sendiri mudah dimengerti oleh pembacanya.

Menurut Hartono (2011), kejelasan (clarity) menunjukkan pengertian yang sama dengan keterbacaan (readability) yang dikemukakan oleh Larson (1984). Hartono dan Larson juga menjelaskan bahwa untuk mengetahui apakah sebuah terjemahan jelas atau tidak, dapat dipahami dengan baik dan mudah atau tidak, penerjemah perlu meminta penutur bahasa penerima (bsa) untuk membaca naskah terjemahannya agar dapat memberitahukan isi naskah/informasi yang disampaikan dalam terjemahan itu.

Senada dengan Hartono (2011) dan Larson (1984), Nababan, dkk.(2012) dan Oakland, T. (2004) menyatakan bahwa keterbacaan atau di dalam bahasa Inggris disebutkan readability, merujuk pada derajat kemudahan sebuah tulisan untuk dipahami maksudnya. Tingkat keterbacaan suatu teks ditentukan oleh beberapa faktor seperti yang dikemukakan oleh Nababan (2012) dan Fitriana (2013) yang meliputi: (1) panjang rata-rata kalimat, (2) jumlah kata baru, dan (3) kompleksitas bahasa yang digunakan. Lebih jauh, Nababan menambahkan faktor-faktor lainnya yang mempengaruhi tingkat keterbacaan suatu produk terjemahan dan mencakup: (1) penggunaan kata/kalimat asingdan daerah, (2) penggunaan kata/kalimat ambigu, (3) penggunaan kalimat yang tidak lengkap, (4) panjang rata-rata kalimat, (5) penggunaan kalimat-kalimat kompleks, dan (6) alur pikiran yang tidak runtut dan tidak logis. Selain faktor yang bersifat kebahasaan di atas, faktor kemampuan membaca dan memahami, serta pengalaman pembaca sangat berpengaruh dalam menentukan keterbacaan suatu teks. 


\section{Kewajaran}

Hasil analisis data kewajaran menunjukkan bahwa dalam dongeng terjemahan Haensel und Gretel ditemukan bentuk-bentuk atau penggunaan bahasa Indonesia yang tidak wajar, yaitu penggunaan bentuk rujukan persona aku dan logika bahasa. Terkait dengan bentuk rujukan persona, Larson (1984) menjelaskan bahwa dalam penerjemahan, penunjukan peran, nomina, dan pronomina harus wajar serta logis dalam bahasa sasaran dan seyogyanya tidak dilakukan secara harfiah. Penerjemah harus selalu ingat siapa orang yang dibicarakan dan bagaimana orang itu dibicarakan dalam bahasa sasaran, misalnya, penerjemahan kata ich dalam bahasa Jerman yang harus diterjemahkan ke dalam bahasa Indonesia menjadi rujukan peran, misalnya ayah, ibu, dan lain-lain, sesuai dengan konteksnya.

Berdasarkan uraian di atas, kewajaran merujuk pada sejauh mana pesan dikomunikasikan dalam bentuk yang lazim sehingga pembaca teks bsa terkesan bahwa naskah yang dibacanya adalah naskah asli yang ditulis dalam bahasanya sendiri. Tidak ada kewajaran yang bersifat universal, bergantung kepada hubungan antara penulis dengan pembaca dan dengan topik atau situasi (Fadaee, 2011). Menurut Sadtono (1985) dan ElBeheri (2015), apabila terjemahan terlalu fokus pada bsu, maka terjemahan tersebut jauh dari alami atau tidak menunjukkan kewajaran.

\section{Pengekspresian Emosi}

Berdasarkan hasil analisis data, aspek emosi yang terdapat dalam dongeng terjemahan Haensel und Gretel terdiri dari emosi kemarahan, emosi ketakutan, emosi kesedihan, emosi kegembiraan, dan emosi ketenangan. Emosi dalam sebuah karya sastra berkaitan erat dengan bahasa.

Sehubungan dengan hal tersebut, Salam (2013) menjelaskan bahwa bahasa punya kekuatan yang dahsyat, dalam upayanya membuat seseorang menjadi tegar, kuat atau bahkan merasa simpatik dan sedih dalam waktu bersamaan. Senang, sedih, bahagia, sengsara, dan emosi lainnya, semua bisa tersampaikan melalui perantara bahasa. Emosi dapat bersifat positif atau negatif. Sehubungan dengan hal tersebut, emosi dasar manusia ditandai dengan kata, frase, atau kalimat yang bermakna kebahagiaan, kemarahan, ketakutan, kejutan, menjijikkan, dan malu (Ekman, 1980). Adapun bentuk penyampaiannya bisa berupa kalimat bebas, dialog, dan humor (Salam, 2013).

Dalam kaitannya dengan penerjemahan, emosi merupakan salah satu aspek penting yang harus mendapat perhatian penerjemah karya sastra.

\section{Gaya Bahasa}

Hasil analisis gaya bahasa yang terdapat dalam dongeng terjemahan Haensel und Gretel menunjukkan bahwa terdapat lima gaya bahasa yang digunakan, yaitu simile, hiperbola, asonansi, repetisi, dan personifikasi. Berikut adalah pembahasan tentang kelima gaya bahasa tersebut.

Gaya bahasa simile atau perbandingan bersifat eksplisit. Gaya bahasa ini ditunjukkan dengan kata-kata: seperti, bagai, laksana, ibarat, bak, dan lain-lain. Ciri-ciri tersebut tidak dimiliki oleh metafora yang merupakan gaya bahasa perbandingan langsung. Tentang penerjemahan simile dan metafora, Larson (1984) mengatakan bahwa langkah pertama menuju terjemahan simile atau metafora yang memadai ialah menentukan apakah perbandingan itu merupakan metafora atau simile hidup atau masih dapat ditentukan makna dasar dari konotasinya sekarang ataukah sekedar metafora mati. Larson juga menjelaskan 
bahwa jika kata yang dihadapi adalah idiom atau metafora mati, maka citra itu tidak perlu dipertahankan, dan maknanya dapat diterjemahkan secara langsung, yaitu dengan ungkapan yang nonfiguratif. Akan tetapi, jika perbandingan itu merupakan metafora atau simile hidup, maka tugas pertama penerjemah adalah menganalisis metafora itu dengan teliti. SnellHornby (1988) dan Newmark (1988) sepakat berpendapat bahwa kesulitan menerjemahkan metafora disebabkan oleh perbedaan budaya sehingga menerjemahkannya secara harfiah sering menimbulkan salah pengertian. Senada dengan mereka, Larson (1984) mengatakan bahwa jika metafora diterjemahkan secara harfiah atau diterjemahkan secara kata demi kata sering menimbulkan makna yang salah, nihil, atau ambigu.

Terkait gaya bahasa hiperbola, Larson (1984) mengungkapkan bahwa hiperbola adalah metonimia atau sinekdoke yang mengungkapkan sesuatu secara berlebihan, dengan membesar-besarkan sesuatu. Hiperbola biasa digunakan untuk menciptakan sebuah efek yang lebih besar daripada "life effect" dan memberi tekanan emosi pada inti pernyataan melalui penggunaan kata-kata dan frase-frase tertentu sehingga bisa diperoleh efek yang lebih besar dan terang. Ungkapan berlebihan itu sengaja digunakan untuk memberi efek tertentu dan disarankan untuk tidak diterjemahkan secara harfiah (Beekman dan Callow, 1974. Reproduksi gaya yang sama, dalam hal ini hiperbola diberi padanan hiperbola merupakan upaya untuk mempertahankan efek yang diharapkan dan sekaligus menyampaikan makna yang tepat.

Temuan tentang adanya penggunaan gaya bahasa asonansi dalam dongeng bsa, diyakini bukan sebagai sebuah kebetulan, karena menurut Haque (2012), tidak ada sebuah kegiatan berbahasa yang bersifat kebetulan. Asonansi banyak digunakan dalam puisi, tetapi penggunaannya dalam prosa, termasuk dongeng juga dapat memberi efek estetis dan penekanan tertentu. Penerjemahan gaya bahasa asonansi dengan gaya bahasa asonansi tentunya merupakan sebuah cara dalam rangka mereproduksi efek estetis yang mendekati efek estetis bsu terhadap pembacanya dan mereproduksi makna secara akurat (analog dari Hartono, 2014).

Gaya bahasa lainnya adalah repetisi. Gaya repetisi dalam dongeng terjemahan ini memberikan efek penegasan, memberi penguatan pada isi cerita, serta memberi warna atau kekhasan pada dongeng tersebut. Oleh sebab itu, sebagaimana disarankan oleh Haque (2012), yaitu bahwa setiap gaya bahasa seyogyanya diupayakan padanannya, maka gaya bahasa repetisi seyogyanya diterjemahkan dengan repetisi pula. Menurut Ben-Ari (1998), dalam karya sastra, repetisi merupakan sebuah gaya yang bernilai tinggi dan dapat diterjemahkan dengan berbagai strategi.

Mengenai gaya bahasa personifikasi atau alegori, Frye, dkk. (1985) menyebut gaya bahasa ini sebagai cara memperlakukan benda-benda, alam, dan binatang seperti manusia atau memiliki karakteristik seperti manusia yang memiliki hasrat, emosi, sensasi, perasaan, dan bisa berpikir, mengambil keputusan, menyanyi, menangis, berbicara, dan lain-lain. Personifikasi, alegori, dan metafora memiliki kemiripan bentuk dan tidak mudah dibedakan. Akan tetapi, keberadaannya di dalam teks mudah dikenali. Sebagai contoh: Das Leben ist schoen, denn die Sonne lacht mir (Hidup ini indah, karena matahari tertawa padaku) dan Justitia entschied, dass es wahr war (Pengadilan memutuskan bahwa itu benar). Efek personifikasi adalah puitisasi, konkretisasi, dan sugesti. Untuk itu, penerjemah harus melakukan berbagai pendekatan, misalnya melalui pendekatan budaya dan pendekatan estetika. 


\section{SIMPULAN}

Dalam terjemahan dongeng Haensel und Gretel ditemukan, pertama, bentuk-bentuk bahasa: kata, frase, dan kalimat yang tidak mudah dipahami dan ambigu sehingga pesan yang ingin disampaikan tidak jelas/tidak begitu jelas. Selain itu, ada pula bentuk-bentuk saduran dari bsu yang membuat teks terjemahan terasa asing.

Kedua, ditemukan juga bentuk-bentuk yang tidak wajar, bentuk-bentuk yang mungkin benar dari segi tatabahasa, tetapi tidak lazim digunakan. Bentuk-bentuk yang tidak wajar tersebut membuat teks begitu terasa sebagai sebuah hasil terjemahan.

Ketiga, pengekspresian emosi ditunjukkan melalui kata, frase, dan kalimat yang menggambarkan kemarahan, ketakutan, kesedihan, kesenangan, dan ketenangan tokoh-tokoh ceritanya. Pengekspresian emosi tersebut menggunakan kalimat langsung (dialog) dan kalimat tidak langsung.

Keempat, dalam terjemahan dongeng Haensel und Gretel ditemukan lima gaya bahasa/majas, yaitu simile, hiperbola, asonansi, repetisi, dan personifikasi. Penggunaan masing-masing gaya bahasa memberi efek khusus terhadap pesan yang disampaikan dan kepada pembaca.

\section{SARAN}

Sesuai dengan temuan-temuan penelitian di atas, disampaikan beberapa saran kepada pihak-pihak yang berkepentingan. Pertama, kepada para penerjemah komersial, disarankan agar lebih memperhatikan kepentingan pembaca bahasa sasaran dengan memperhatikan aspek kejelasan dan kewajaran bahasa terjemahan sehingga mereka dapat memahami teks terjemahan dengan mudah. Kedua, kepada para mahasiswa, khususnya yang berkomitmen untuk menjadi penerjemah disarankan agar terus meningkatkan penguasaan bsu dan bsa dan meningkatkan pemahaman budaya bsu dan bsa. Hal tersebut merupakan perangkat intelektual utama dalam penerjemahan. Ketiga, para dosen pengampu matakuliah penerjemahan disarankan agar meningkatkan kualitas perkuliahan penerjemahan tersebut sehingga para lulusannya bisa menghasilkan karya-karya terjemahan yang berkualitas. Keempat, para peneliti bidang penerjemahan disarankan untuk meneliti dan mengkritisi karya-karya terjemahan. Hasil penelitiannya dapat dijadikan sebagai dasar pijakan bagi institusi penyelenggara pendidikan/pembelajaran penerjemahan dalam menentukan kebijakan sehubungan dengan upaya peningkatan kualitas dosen pengampu matakuliah penerjemahan. Selain itu, hasil penelitian karya-karya terjemahan, khususnya terjemahan karya sastra dapat digunakan sebagai petunjuk praktis oleh editor dan penerbit.

\section{DAFTAR RUJUKAN}

Ahmad, H. 2013. "Menyoal Karya Sastra Terjemahan Kita”. Horison Online.(Online).horisononline.or.id/id/esai/1239, diakses April 2015.

Beekman, J dan John, C. 1974. Translating The Word of God. Grand Rapids, Michigans: Zondervan.

Ben-Ari, Ni. 1998. «The Ambivalent Case of Repetitions in Literary Translation. Avoiding Repetitions : a "Universal" of Translation?» Meta, XLIII, 1, 1998. (Online), http://www.erudit.org/revue/META/1998/v43/n1/002054ar.pdf, diakses September 2016.

Damono, S.D. 2013. Kebudayaan (Populer) (Di Sekitar) Kita. Jakarta: editum. 
Ekman, P., Friesen, W. V., \& Ancoli, S. 1980. "Facial Signs of Emotional Experience".Journal of Personality and Social Psychology, 39(6), 1125-1134.(Online), https://www.paulekman.com/wp-content/uploads/2013/07/Facial-Sign-Of-EmotionalExperience.pdf, diakses 10 Nopember 2015.

ElBeheri, N.R. 2015. Clarity as a Solution for more Creative Translation Teaching Methods. Journal of Educational Policy and Entrepreneurial Research (JEPER), Vol.2, N0.1, January 2015. Pp 17-28. (Online), http://www.iiste.org/journals/index.php/JEPER, diakses 31 Januari 2017.

Fadaee, E. 2011.Translation naturalness in literary works: English to Persian . Internal Journal of English and Literature Vol. 2(9), pp. 200-205, December 2011. (Online) http://www.academicjournals.org/ijel, diakses September 2014.

Fitriana, I. 2013. "Penerjemahan Karya Sastra Anak". Diglosia, vol.4.No. 2. 2013. (Online), www.journal.unipdu.ac.id, diakses Mei 2015.

Frye, et al. 1985.The Harper Handbook Literature. New York: Harper\& Row, Publishers.

Glodjović, A. 2010. Translation as a Means of Cross-Cultural Communication: Some Problems in Literary Text Translations. FACTA UNIVERSITATIS Series: Linguistics and Literature Vol. 8, No. 2, 2010, pp. 141 - 151. (Online), https://philpapers.org/rec/GLOTAA-2, diakses Oktober 2014.

Hartono, R. 2011.Penerjemahan Idiom dan Gaya Bahasa (Metafora, Kiasan, Personifikasi, dan Aliterasi) dalam Novel To Kill A Mockingbird Karya Harper Lee dari Bahasa Inggris ke Bahasa Indonesia (Pendekatan Kritik Holistik). Disertasi tidak diterbitkan. Surakarta: Program Pascasarjana UNS. (Online), http://eprints.uns.ac.id/6334/, diakses Oktober 2014.

Hartono, R. 2014. "Problematika dalam Penerjemahan Novel". Prosodi, Vol. 6, No. 2. (Online).http://journal.trunojoyo.ac.id/prosodi/article/view/58/80, diakses 30 Oktober 2015.

Haque, Md.Z. 2012. "Translating Literary Prose: Problems and Solutions". International Journal of English Linguistics: Vol.2, No.6, 2012. (Online).www.ccsenet.org >, diakses Mei 2015.

Helmling, B dan Gustav W. 1986. Literatur im Deutschunterricht am Beispiel von narrative Texten. München: Goethe-Institut.

Hervey, S; L, M und H, I. 2006.Thinking German Translation. London: Routledge.

Kadric, M; kaindl, K. und Kaiser-Cooke, M. 2010.Translatorische Methodik. Wien: facultas.wuv.

Larson, M. L. 1984. Penerjemahan Berdasar Makna. Terjemahan Taniran Kencanawati. 1991. Jakarta: Arcan.

Machali, R. 2009. Pedoman bagi Penerjemah. Bandung: Kaifa.

Mansor, I. 2012. "Acceptability" in The Translation into Malay of Rihlat Ibn Battutah". Kemanusiaan.Vol. 19, No. 2.(2012), 1-1. Malaysia: Universiti Saints Malaysia. (Online).http://web.usm.my/kajh/vol19_2_2012.html, diakses Maret 2015.

McCaughrean, G. 2003. 20 Dongeng Terbaik Sepanjang Masa.Terjemahan Debbie Natalia. 2013. Jakarta: PT. Gramedia Pustaka Tama.

Miles, M dan Huberman, M. 1984. Qualitative Data Analyses: A Source Book for New Methods. Beverly Hills,CA: Sage Publications.

Moleong, L. J. 2007. Metode Penelitian Kualitatif. Jakarta: PT Remaja Rosdakarya.

Nababan, M. 2012. "Pengembangan Model Penilaian Kualitas Terjemahan". Kajian Linguistik dan Sastra 24 (1) 39-57. Surakarta: Universitas Muhammadiyah Surakarta. 
Newmark, P. 1988. A Textbook of Translation. Oxford: Pergamon Press.

Nurgiyantoro, B. 2005. Sastra Anak: Pengantar Pemahaman Dunia Anak. Yogyakarta: Gajahmada University Press.

Oakland, T. and Lane, H. (2004). Language, Reading, and Readability Formulas: Implications for Developing and Adapting Tests. International Journal of Testing, 4, 239252, diakses Juni 2016.

Sadtono, 1985. Pedoman Penerjemahan. Jakarta: Pusat Pembinaan dan Pengembangan Bahasa Depdikbud.

Salam. 2013. "Bentuk dan Jenis Bahasa Emosional dalam Bahasa Tolaki”. KOLITA 11, Cet. 1-Edisi 1-2013. (Online), http://repository.ung.ac.id/karyailmiah/show/212/bentuk-danjenis-bahasa-emosional-dalam-bahasa-tolaki.html.

Salam, A. 2001. Sastra Terjemahan-Beberapa Persoalan. Universitas Gajah Mada. (Online), https://www.academia.edu/1490358/Sastra_Terjemahan.

Snell-Hornby, M. 1988. Translation Studies: An Integrated Approach. Amsterdam: Benjamis.

Yin, R. 1994. Case Study Research: Design and Methods (edisi kedua). Thousand Oaks, CA: Sage Publishing. 